\title{
Employee Intention to Stay: An Environment Based on Trust and Motivation
}

\author{
Dr. Amena Shahid (Corresponding author) \\ Pilon School of Business, Sheridan College Institute of Technology and Advanced Learning \\ Davis Campus, 7899 McLaughlin Road, Brampton, Ontario L6Y 5H9, Canada
}

Tel: 1-416-890-2907 E-mail:amena.shahid@sheridancollege.ca

Received: April 26, $2018 \quad$ Accepted: Sep. 28, $2018 \quad$ Published: October 1, 2018

doi:10.5296/jmr.v10i4.13680

URL: https://doi.org/10.5296/jmr.v10i4.13680

\begin{abstract}
An organization effort to recognize the reasons for employee retention can serve to keep turnover down. No matter what industry it is essential to comprehend what the employees think and sense about the organization and the working culture. A supportive and positive work environment instilled by motivation and trust strengthens the connection between an organization and employee. When organizational leaders naturally respect employees as more than mere work resources, employees reach a high level of performance and will continue with the organization longer. The primary objective of this study was to recognize and promote the factors of trust and motivation influencing a positive working environment and employees intentions to stay with the organization. The study aims to determine elements of employee intent to stay and contribute to the growing body of literature on the significance of trust, motivation and positive working environment.
\end{abstract}

Keywords: Trust, motivation, intent to stay, organizational culture, employee retention 


\section{Introduction}

Organizational positive and supportive environment has become essential processes for an organization in recent years. Research on positive organizational psychology shows that a positive environment will drive compelling benefits for employers, employees, and the bottom line. Employees leave organizations if they are not satisfied with multiple factors linked to the company. According to Branham (2005), there are seven main reasons why employees leave, which are lack of recognition, low pay, unfulfilling jobs, inadequate career advancement, poor management practices, untrustworthy leadership, and disordered work cultures. While a positive work climate needs to be formed, productive and professional, a conducive workplace also requires to be a positive one. Employees working in a positive work environment exhibit more supported trusted and motivated to do their best. These employees are happier with their job and more inclined to stay with their company longer.

Employees who trust their organization's management do better, are more satisfied, more loyal, and are less prone to oppose changes (Dirks and Ferrin, 2002). Trust, as an essential lubricant of the social system (Arrow, 1974), must be set in organizations. Trust is not only significant to build the enduring relations with the external stakeholders; it is a vital element to increase the internal ties (Serkan, 2018). The eagerness of employees to work and stay in an organization depends on the level to which they are sufficiently motivated (Adams and Hicks, 2000). Therefore, the primary objective of this study is to examine the relationships between trust and motivation practices and employee intent to stay.

\section{Literature Review}

The intention is a psychological antecedent for the actual behavior (Ajzen and Fishbein, 1980), individuals' intention to stay or quit, perform or not to perform a behavioral act can be the critical determinant of action. Intention to stay is the opposite of turnover intention (Kim, Price, Mueller and Watson, 1996) are negatively correlated, (Steers and Mowday, 1981). Employee turnover hinders the organization's work reaching its goals, profit of the organization and damaging the organization as a whole. Intention to stay is defined as employees' intention to stay in the existing employment relationship with their current employer on a long-term basis.

Vandenberg and Nelson (1999) defined employees' intention to quit as an individual's predicted probability that they are permanently departing from their organization soon. Unwelcome, unwanted, and voluntary attrition that companies encounter when valued employees quit accepting another job is a more significant issue than the incidence of organizational layoffs reported (Mobley, 1982). This perspective is growing significantly as the competition for talent management is leading and consistently growing. People want to know that their participation in the organization is appreciated. To retain employees in the company, they want to feel part of the organization. For the problem about employees leaving, specific appropriate actions need to be taken as organizations are striving for talent (Mitchell, Holtom, and Lee, 2001). 
The focus turns to describe how to incorporate trust into an organization, trust strengthening strategies, and intent to leave. Organizational trust is promoted by the attribution of positive relationships (Cox, Jones, \& Collinson, 2006). Antelo, Henderson, and St. Clair (2010) suggested research in workgroup motivation and organizational trust indicated that single worker motivation manage performance and productivity and leaders need to recognize what motivates followers aiming for excellent performance. The identification of the factors that improve employee motivation and trust in a company aid to predict an employee's intent to leave and provide greater knowledge of the individual motivators of employees. According to several researchers (Brown \& Trevino, 2009; Dowling, 2006; Edwards \& Cable, 2009), the study of trust and its effect on intent to leave is still generally considered a current area of research and indicates a deficiency in meaningful definitions that could apply within all facets of organizations. Research on intent to leave focuses highly on the perceptions that effective leadership has an unambiguous effect on employee motivation and morale and therefore should receive adequate consideration (Udechukwu \& Mujtaba, 2007). Organizations continuously try to learn how to retain quality employees, build trust, and develop employee motivation. Therefore, the purpose of this study was to investigate the perceptions of employees regarding the relationships of organizational trust, motivation, and intent to leave and to recommend strategies that may guide to increases in employee intent to stay.

\subsection{The Role of Trust in Employee Intention to Stay}

An environment of open trust generates an ambiance of open communication, strengthen performance, and organizational value improving strategies. Lebow and Simon (1997) described that leadership should be real and significant believing in mentoring, openness and trust. According to Ellis and Shockley-Zalabak (2001), trust is a favorable assumption about the behavior of others defined by roles, connections, skills, and reliance. An acceptance of trust and or mistrust guides individuals to believe in other people's actions or intentions. Trust can affect the way an individual understands, recognizes, and performs.

Organizational theorists are naive that trust develops and lives at all levels of the organization. Trust in an organizational connection formed through a culture of interaction and leadership. An employee's view of organizational trust and communication is an essential determinant in creating a successfully cohesive and positive working environment (Gilbert \& Tang, 1998). From an organizational viewpoint, managers and supervisors need to make trust evident and provide enough models of trustworthy behavior. When trust is lost in the work environment, the open synergy and sharing of ideas tend to exhaust (Adams, 2004). Individual growth and development are robust to accomplish when people are restricted to trust in themselves and others they depend on (Haskins, 1996). Employee observation of organizational trust is vital because employee opinions are usually based on assumptions and can grow and change over time (Gioia, Shultz, \& Corley, 2000).

Employees make their perceptions about the working atmosphere based on their practices, participation, and engagement with other employees or even as a customer or representative of the organization (Caldwell \& Clapham, 2003). Kramer (1999) and Brooks (2007) 
emphasized the relevance and significance of promoting trust when executing changes within an organization. The concept of trust-based organizations and organizational trust-driven companies need sufficient evidence to measure the results, both positive and negative.

Increased levels of trust within an organization could show positive results in an employee's viewpoint of organizational and job commitment. Dirks (2000) accepted and reported that organizational trust could drive a link that can undoubtedly influence an employee's achievement and productivity. A positive aspect of organizational trust could lead to participation and recognition among staff, compliance, and motivation to work, and overall organizational progress. Corporations can develop trust by combining their approaches and goals into their organizational goals and implementing consistently throughout the company. Trust can mold the behaviors and views of workers to the values of the company building an environment where people desire to work that employees' trust in leadership could strengthen their commitment and devotion to the organization and reduce the distress about leaving the organization. Organizational trust is a decisive determinant in an employee's illustration of organizational trust and the choice to continue with an organization.

\subsection{The Role of Motivation in Employee Intention to Stay}

Employees play a pivotal role in the progress of any organization. In today's dynamic business climate, it has become vital to practice human resource (HR) methods to retain employees performed with the organization's goals. Motivation symbolizes "those psychological process that creates arousal, direction, and persistence of voluntary actions that are goal oriented" (Mitchell, 1982. p. 81). Motivation improving practices assist in motivating performance and effort. According to Shenkel \& Gardner (2004), motivating employees is complex for organizations: if the right conditions or motivational factors are not in place, it will occur in weak performance, low satisfaction, diminishing morale and great despair. Amabile (1993) explained that it is necessary for managers and organizations to recognize and understand how to deal efficiently with their employees' motivation since motivated employees are vital to assure the organization grows successfully.

Motivation can be divided into two primary kinds: extrinsic and intrinsic motivation. Extrinsic motivation can be observed as external factors, which can be defined in monetary terms, such as salary, benefits, promotions, and incentives. Amabile (1993) emphasizes that individuals are extrinsically motivated when they engage in work to achieve some purpose that is different from the work.

Intrinsic motivation, on the other hand, leads to internal factors such as job satisfaction, responsibility, the choice to act and development of skills and abilities. Individuals that are intrinsically motivated are often seen as self-motivated because they experience the real tasks. These two distinct features of motivation are related to each other and cannot be in isolation. Amabile (1993) affirms that both intrinsic and extrinsic factors can motivate employees to perform positively. However, both elements can have varying impacts on employees. 


\subsection{Role of Leadership In Employee Intention to Stay}

According to Caldwell and Dixon (2010), trust, support, and forgiveness are essential values used by leaders. The individual in leadership roles within an organization managing employee with respect and dignity can enhance the performance of the employees. The study on leadership continues to build to develop into more directed disciplines in the present business environment (Early and Davenport 2010). Trust and accountability for retaining the talent required to be in the hands of leaders. Leaders and their ability in creating a climate of retention, a culture that delivers to employees in a way that promotes them to stay, will be an organization's best safeguard against undesired turnover. Employees are more inclined to stay with an organization when they feel that leaders display care and concern for them, if they are given a role that suits their skills and gets constant positive feedback and recognition. The quality of connection an employee has with his or her managers extends employee stay in an organization (Ferreira, 2007 cited in Michael, 2008).

Understanding the concept of leadership is vital in studying the relationship between leadership style and intent to stay. Organizations require strong leaders to inspire and support their employees. Leaders' skills to inspire, motivate, and satisfy their employees are important drivers of employees' intent to stay with their organizations (Shuck \& Herd, 2012). Leaders who are more efficient are expected to engage their employees. Kim and Jogaratnam (2010) studied how individual and organizational determinants influence job satisfaction and employee intent to stay in the hotel and restaurant industry. In their study, Kim and Jogaratnam used data from a survey of 221 hotel and restaurant employees. Direct leader leadership was one of the independent variables of the study. Direct leader leadership is a leadership style that concentrates on the achievement of tasks and progress of subordinates (Kim \& Jogaratnam, 2010). The results of Kim and Jogaratnam's study showed that direct leader leadership does not hit job recognition, but it is a strong predictor of employees' intention to stay with the organization.

Long and Thean (2011) study indicated a negative association between transformational leadership and turnover intention, meaning that transformational leadership can develop the intention to stay. Wells and Peachey (2011) adopted transformational leadership and transactional leadership as leadership styles variables. The results revealed that both transformational leadership and transactional leadership styles are likely to increase intent to stay with the organization. To know the relationship between leadership and retention of nurses, Forest and Kleiner (2011) examined the results of the nursing management style, which is transactional leadership, on nurses' retention and recruitment. The outcome showed that transactional leadership decreases nurses' moral, and increases their turnover retention. Forest and Kleiner suggested transformational leadership and explained that this leadership style is expected to enable nurses and improve their intention to stay. Several studies (Furtado, Batista, \& Silva, 2011; Forest \& Kleiner, 2011) indicated that leadership style is a positive predictor of intent to stay.

Samuel and Chipunza (2013) noted that acquiring skilled employees motivates managers to increase employee retention and ensure employees do not leave the organization. Employees 
intend to stay with an organization if the organizational leaders support their well-being; if employees are aware of the employers' expectations of them; if employees felt confident and assured that they are the right candidate for the job; and if the organizational leaders implement excellent employee recognition programs. Effective retention strategies increased employee motivation and intent to stay with an organization and led to a decrease in turnover intention.

\section{Organizational Practices to Employee Retention}

The workforce is a critical element of any organization, and therefore employees are always recognized as the most significant resource of an organization. Without employees, organizations will not be capable of delivering business outcomes, accomplish organization aims, or reach its financial objectives. Most organizations understand the value of human resources in achieving the success of their businesses. Without a skilled workforce, the company would not be able to grow to reach business or organizational goals (Mobley, 1982; Taylor, 2002).

Employee retention and job satisfaction should be on each organization's priorities, and building active retention strategies should be one of management's primary jobs. Employees leave an organization from disappointment and endless discord with their superiors or other team members. Additionally, low pay, the absence of growth possibilities and motivation enforce an employee to look for a change. It is the organization priority to retain the employees who are truly significant for the system and are productive contributors. To get the best use of company skill and for optimal consumption of the resources, the human resource must be handled correctly and dealt properly. Employees developing their skills and establish as a worthy employee towards a company and to the customers are the distinct resource.

Ratna and Chawla (2012) reported organization strategies and practices that enhance employee retention for long-term employment. Having small opportunities to grow within an organization is a hurdle for retaining employees, and the ambitious job market will lead to a loss of employees' abilities, learning, and expertise (Uzonna, 2013). A cause of dissatisfaction at work is conflicts in employees' work-life balance, and the way management maintains the balance (Gilley, Waddell, Hall, Jackson, \& Gilley, 2015). Managers can improve meaningfulness for their employees through effective management practice, equality and freedom, and participation and connectedness (Price, 2013).

\subsection{Leading a Culture of Organizational Trust}

If trust is constituted by members' understandings of knowledge, kindness, and integrity, then organizations should strategically lead these thoughts to strengthen trust levels by what they do and how they do it. This institutional trust (McKnight, Cummings, \& Chervany, 1998) is formed through such decisive actions as managing to support policies and procedures, selecting and training team leaders and members, and explicitly defining tasks, roles, and responsibilities. An organization's trustworthiness is endangered when leaders neglect to recognize the time and cultural variations across team members, when reward systems center on individual rather than group achievement, or when team members are not trained to know 
each other or the distinct demands of their project. An attempt by management building a culture of positive employee well-being promotes employee retention. Organizational leaders need to distinguish between productive and dependable employees and nonproductive employees. An employee's departure leads to the loss of knowledge, customer loyalty, and morale among employees. The need to recognize the achievements and commitment of the workforce within an organization is apparent. Organizational leaders should cultivate a cooperative environment for consistent employee retention.

Therefore, trust is an inherent part of the performance of an organization (Van der Berg and Martins 2013) and is the employee's expectation on the authenticity in the organization's assurances and actions (Politis 2003). Trust boosts the effectiveness of communication (Blomqvist 2002), as well as organizational participation and collaboration (Mayer et al. 1995; Tyler 2003). It has also been recognized as a crucial factor in leadership effectiveness (Tyler 2003), employee satisfaction (Shockley-Zalabak et al.2000), commitment (Dirks and Ferrin 2001), and productivity (Huang et al. 2007; Kerce and Booth-Kewley 1993; May et al. 1999). According to Long et al. (2003), inspiring leaders is the best way to develop trust between employees and an organization to strengthen its effectiveness. Bibb and Kourdi (2004) asserted that when trust endures within an organization, various results can be reached. To accomplish individual and organizational goals, the relationship between different people and different life experiences is essential. The trust facilitates this interdependence. An inspiring and trusted organizational culture achieves employee commitment within an organization. An employee realizing being considered, understood and appreciated increases commitment.

\subsection{Leading a Culture of Motivation}

Motivational dynamics have shifted revealing new work conditions and altered worker expectations. The level of achievement of employees depends not only on their fundamental skills but also on the level of motivation each person displays. High-achievers, skilled employees are the inspirational power of all institutions and organizations try to motivate and hold on to the best employees. Concern for a specific combination, engagement flexibility, and quality, has called for study for employees motivation and retention.

Motivation impacts employee performance and productivity and is more oriented towards autonomy and are more self-driven (Shahzadi et al., 2015). Motivation provides a path to follow (Ilagan et al., 2014). A study by Ebeling and Gustafsson (2012) in Ilagan (2014) observed evidence of the function of culture in learning people's motivations and opportunity for achievement. Employee motivation is a globally studied exercise today across all corporate sectors, despite their size. It indicates concentrating on the psychological need for any person is to be recognized for his efforts, through rewards and recognition to enhance the work initiative. Motivation It stimulates employees; develops employees' levels of performance and allows organizations to achieve a sustainable competing advantage over their competitors (Mohsan, Nawaz, Khan, Shaukat, \& Aslam, 2011). In a study by Kubo and Saka (2002), factors such as financial incentive, human resource development, and job autonomy were recognized as motivators for employees serving in the Japanese financial sector. From 1924 to 1932, Elton Mayo conducted a study related to as Hawthorne Studies. It 
found that employees are not motivated only by money, but employee motivation is connected to their characters (Dickson, 1973).

These studies declared the origin of the human relations approach to management, whereby the needs and motivation of employees became the primary focus (Bedeian, 1993). Compensation has a significant impact on employee recruitment, motivation, productivity and turnover (Bernardin \& Russel, 1993). It is the financial returns for the services contributed by employees as part of employment ties. According to Bernardin and Russel's (1993) research, employees were satisfied and more intrinsically motivated to give a high-quality achievement when rewarded with money. Job characteristics also represent a role in how employees encounter motivation, satisfaction, and turnover. Also, work environment characteristics describe the conditions in which the employee works, climate, structure, agendas, roles, and stress, all of which are unique to an organization. Brown and Shepherd (1997) reported that motivation improves workers' job satisfaction. Stokes, Riger, and Sullivan's (1995) research conclusions indicated that motivation links to job satisfaction and the employees' intention to stay in the organization. Thus job dissatisfaction due to the absence of motivation influences the organization to high turnover. Job satisfaction seems to create high levels of employee motivation that tends to lower turnover (Wan-Huggins, Riordan, \& Griffeth, 1998). This view is also supported by a study conducted by Sajjad, Ghazanfar, and Ramzan (2013) on the banking environment in Pakistan.

\section{Conclusion}

The literature indicates the importance of organizational trust and employee motivation for employee intention to stay within the organization. The literature indicates the importance of organizational trust and employee motivation for employee intention to stay within the organization. The motivated employees' works best in the interest of the organizations which drives them towards growth, success, and productivity. Thus the employee motivation, trust is directly related to a positive and supportive working environment. Organizations should create and advance such working cultures that promote trust and motivation. The first lesson one must learn is that organizations cannot motivate or insert trust in any of the employees. Organizations provide an environment in which it becomes possible for the employees to satisfy their growth and development needs, progress and connect with the employer.

\section{References}

Adams, O. \& Hicks, V. (2000, December). Re: Pay and non-pay incentives, performance, and motivation [Roundtable discussion group]. Retrieved from http://www.who.int/hrh/en/HRDJ_4_3_02.pdf

Adams, S. H. (2004). The relationships among adult attachment, general self-disclosure, and perceived organizational trust. (Doctoral dissertation). Retrieved from http://www.scholar.lib.vt.edu/theses/available/etd-032504150617/unrestricted/SamAdamsRevDissertationFinal.pdf 
Ajzen, I. \& Fishbein, M. (1980). Understanding attitudes and predicting social behavior. Englewood Cliffs, NJ: Prentice Hall.

Amabile, T. (1993). Motivational synergy: Toward new conceptualizations of intrinsic and extrinsic motivation in the workplace. Human Resource Management Review, 3(3), 185-201. http://dx.doi.org/10.1016/1053-4822(93)90012-S

Antelo, A., Henderson, R., \& St. Clair, N. (2010). Understanding the process model of leadership: Follower attribute design and assessment. Journal of College Teaching and Learning, 7(4), 9-14. http://dx.doi.org/10.19030/tlc.v7i4.108

Arrow, K.J. (1974), The limits of organization, Norton, York, New York, NY [Cited in Berg, J., Dickhaur, J., McCabe, K. (1995). Trust, reciprocity, and social history. Games and Eco.nomic Behavior, 10, 122-142]

Bedeian, A. G. (1993). Management. New York, NY: Dryden Press.

Bernardin, H. J., \& Russel, J. E. A. (1993). Human resources management: An experiential approach. New York, NY: McGraw-Hill.

Bibb, S. \& Kourdi, J. (2004). Trust Matters for Organizational and Personal Success. Basingstoke: Palgrave Macmillan.

Blomqvist, K. (2002). Partnering in the dynamic environment: the role of trust in asymmetric technology partnership formation ( $\mathrm{PhD}$ thesis). Retrieved from https://www.researchgate.net/profile/Kirsimarja_Blomqvist/publication/34002604_Partnering _in_the_Dynamic_Environment_The_Role_of_Trust_in_Asymmetric_Technology_Partnersh ip_Formation/links/0fcfd505ad7cd07673000000.pdf

Branham, L. (2005). The 7 hidden reasons employees leave - How to recognize the subtle signs and act before it's too late. Amacom: Saranac Lake, NY.

Brooks, A. (2007). It's all about the motivation: Factors that influence employee motivation in organizations. (Doctoral dissertation). Retrieved from https://trace.tennessee.edu/cgi/viewcontent.cgi?referer $=\&$ httpsredir=1\&article=5926\& context $=$ utk_graddiss

Brown, C. M., \& Shepherd, N. (Eds.). (1997). Job satisfaction factors. New Delhi: Griffin.

Brown, M. E., \& Treviño, L. K. (2009). Leader-follower values congruence: Are socialized charismatic leaders better able to achieve it? Journal of Applied Psychology, 94(2), 478-490. http://dx.doi.org/10.1037/a0014069.

Buble, M. (2011). Poslovno vođenje. Stega Tisak, Zagreb. Retrieved from https://www.scribd.com/document/257764366/POSLOVNO-VODENJE-MBuble-pdf

Caldwell, C., \& Clapham, S. E. (2003). Organizational trustworthiness: An international perspective. Journal of Business Ethics, 47(4), 349-358. http://dx.doi.org/10.1023/A:1027370104302 
Caldwell. C \& Dixon, R. (2010), Love, forgiveness and trust: critical values of the modern leader. Journal of Business Ethics, 93(1), 91-101. http://dx.doi.org/10.1007/s10551-009-0184-z

Cox, S., Jones, G., \& Collinson, D. (2006). Trust relations in high-reliability organizations. Risk Analysis, 26(5), 1123-1136. http://dx.doi.org/10.1111/j.1539- 6924.2006.00820.x

Dickson, W. J. (1973). Hawthorne experiments. In C. Heyel (Ed.), The encyclopedia of management (2nd ed., pp. 298-302). New York: Van Nostrand Reinhold.

Dirks, K.T. (2000). Trust in leadership and team performance: evidence from National Collegiate Athletic Association (NCAA) basketball. Journal of Applied Psychology, 85(6), 1004-1012. http://dx.doi.org/ 10.1037/0021-9010.85.6.1004

Dirks, K. \& Ferrin, D. (2001). The role of trust in organizational settings. Organization

Science, 12 (4), 450-67. http://dx.doi.org/10.1287/orsc.12.4.450.10640

Dirks, K.T. \& Ferrin, D.L. (2002). Trust in leadership: Meta-analytic findings and implications for research and practice. Journal of Applied Psychology, 87(4), 611-628. http://dx.doi.org/10.1037//0021-9010.87.4.611

Dowling, G. (2006). How good corporate reputations create corporate value. Corporate Reputation Review, 9(2), 134-143. http://dx.doi.org/10.1057/palgrave.crr.1550017

Early. J \& Davernport,J. B. (2010). Desired qualities of leaders within today's accounting firm. The CPA Journal, 80(3), 59. Retrieved from https:/www.questia.com/magazine/1P3-1996041631/desired-qualities-of-leaders-within-toda y-s-accounting

Edwards, J., \& Cable, D. (2009). The value of value congruence. Journal of Applied Psychology, 94(3), 654-677. http://dx.doi.org/10.1037/a0014891

Ellis, K., \& Shockley-Zalabak, P. (2001). Trust in top management and immediate supervisor. The relationship to satisfaction, perceived organizational effectiveness, and information receiving. Communication Quarterly, $\quad$ 48(4), http://dx.doi.org/10.1080/01463370109385637

Forest, M., \& Kleiner, B. (2011). Effects of current nursing management styles on the retention and recruitment of nurses: A review of the literature. International Journal of Management, 28(4), 254-262. Retrieved from http://www. internationaljournalofmanagement.co.uk/

Furtado, L., Batista, M., \& Silva, F. (2011). Leadership's impact in turnover and career abandonment intention: The Azorean hospital nurses case. Hospital Topics, 89(3), 51-58. http://dx.doi.org/10.1080/00185868.2011.596797 
Gioia, D. A., Schultz, M., \& Corley, K. G. (2000). Organizational identity, image, and adaptive instability. Academy of Management Review, 25(1), 63. http://dx.doi.org/10.5465/AMR.2000.2791603

Gilbert, J., \& Tang, L. (1998). An examination of organizational trust antecedents. Public Personnel Management, 27(3), 1-18.http://dx.doi.org/10.1177\%2F009102609802700303

Gilley, A., Waddell, K., Hall, A., Jackson, S. A., \& Gilley, J. W. (2015). Manager behavior, generation, and influence on work-life balance: An empirical investigation. Journal of Applied Management and Entrepreneurship, 20(1), 3-23. http://dx.doi.org/10.1177/0969733012452684

Haskins, W. A. (1996). Freedom of speech: Construct for creating a culture which empowers organizational members. Journal of Business Communication, 33(1), 1-14. http://dx.doi.org/10.1177/002194369603300108

Huang, T., Lawler, J. \& Lei, C. (2007). The effects of quality of work life on commitment and turnover intention. Social Behavior and Personality, 35(6), 735-750. http://dx.doi.org/10.2224/sbp.2007.35.6.735

Ilagan, J.R., A, Ma., Hechanova, R.M., Anne C. T.. \& Pleyto, V.J. (2014). "Bakit Ka Kumakayod?" Developing a filipino needs theory of motivation. Philippine Journal of Psychology, 47(1),17-143. Retrieved form https:/www.pap.org.ph/sites/default/files/upload/pjp2014-47-1-pp117-143-ilaganhechanovac opleyto-bakit_ka_kumakayod_developing_a_filipino_needs_theory_of_motivation.pdf

Kerce, E.W. \& Booth-Kewley, S. (1993). Quality of work life surveys in organizations: Methods \& Benefits. In: Rosenfeld, P., Edwards, J.E. and Thomas M.D. (Eds.), Improving organisational surveys: New direction, methods and applications. Newbury Park: Sage Publications, 158-209.

Kim, S., Price, J. L., Mueller, C. W. \& Watson, T. W. (1996). The determinants of career intent among physicians at a U.S. Air Force hospital. Human Relations, 49(7), 947-976. http://dx.doi.org/10.1177\%2F001872679604900704

Kim, K., \& Jogaratnam, G. (2010). Effects of individual and organizational factors on job satisfaction and intent to stay in the hotel and restaurant industry. Journal of Human $\begin{array}{lllll}\text { Resources in Hospitality } \quad \& \quad \text { Tourism, } & 9(3),\end{array}$ http://dx.doi.org/10.1080/15332845.2010.487043

Kramer, R. M. (1999). Trust and distrust in organizations: Emerging perspectives, enduring questions. Annual Review of Psychology, 50(2), 569-598. http://dx.doi.org/10.1146/annurev.psych.50.1.569

Kubo, I., \& Saka, A. (2002). An inquiry into the motivation of knowledge workers in the Japanese financial industry. Journal of Knowledge Management, 6(3), 262-271. http://dx.doi.org/10.1108/13673270210434368. 
Lebow, R., \& Simon, W. L. (1997). Lasting change: The shared values process that makes companies great. Hoboken, NJ: Wiley.

Long, C.P., Sitkin, S.B. \& Cardinal, L.B., (2003). Managerial action to build control, trust, and fairness in organizations: The effect of conflict, presented at the International Association of Conflict Management Conference, Melbourne, 2003. Australia

Long, C. S., \& Thean, L. Y. (2011). Relationship between leadership style, job satisfaction and employees' turnover intention: A literature review. Research Journal of Business Management, 5(3), 91-100. http://dx.doi.org/10.3923/rjbm.2011.91.100

May, B.E., Lau, R.S. \& Johnson, S.K. (1999). A longitudinal study of quality of work life and business performance. South Dakota Business Review, 58 (2), 3-7. Retrieved from https://www.thefreelibrary.com/A+Longitudinal+Study+of+Quality+of+Work+Life+and+Bu siness+Performance.-a059285147

Mayer, R., Davis, J. \& Schoorman, D. (1995). An integrative model of organizational trust, Academy of Management Review, 20(3), 709-734. http://dx.doi.org/ 10.5465/amr.1995.9508080335

McKnight, D. H., Cummings, L. L., \& Chervany, N. L. (1998). Initial trust formation in new organizational relationships. Academy of Management Review, 23(3), 473-490. http://dx.doi.org/10.5465/amr.1998.926622

Michael, S.O. (2008). Using Motivational Strategy as Panacea for Employee Retention and Turnover in Selected Public and Private Sector Organizations in the Eastern Cape Province of South Africa: (Master of Commerce Thesis). Available from ResearchGate database.

Mitchell, T. R., Holtom, B. C. \& Lee, T. W. (2001). How to keep your best employees: Developing an effective retention policy. Academy of Management Executive, 15(4), 96-107. http://dx.doi.org/10.5465/ame.2001.5897929

Mitchell, T.R. (1982). Motivation: New directions for theory, research, and practice. The Academy of Management Review, 7(1), 80-88. http://dx.doi.org/10.5465/amr.1982.4285467

Mobley, W. H. (1982). Intermediate linkages in the relationships between job satisfaction and employee turnover. Journal of Applied Psychology, 62(2), 237-240. http://dx.doi.org/10.1037/0021-9010.62.2.237

Mohsan, F., Nawaz, M. M., Khan, M. S., Shaukat, Z., \& Aslam, N. (2011). Are employee motivation, commitment and job involvement inter-related? Evidence from banking sector of Pakistan. International Journal of Business and Social Science, 2(17), 226-233. Retrieved from www.ijbssnet.com

Politis, J. (2003). The connection between trust and knowledge management: What are its implications for team performance? Journal of Knowledge Management, 7 (5), 55-66. http://dx.doi.org/10.1108/13673270310505386 
Price, M. (2013). Cultural attributes and retention strategies within millennial-founded and millennial-run companies. Retrieved from www.pepperdine.edu

Ratna, R., \&, Chawla, S. (2012). Key factors of retention and retention strategies in telecom sector. Global Management Review, 6(3), 35-46. Retrieved from http://www.sonamgmt.org/ gmr . html

Sajjad, A., Ghazanfar, H., \& Ramzan, M. (2013). Impact of motivation on employee turnover in the telecom sector of Pakistan. Journal of Business Studies Quarterly, 5(1), 76-92. Retrieved from http://jbsq.org

Samuel, M. A., \&, Chipunza, C. (2013). Attrition and retention of senior academics at institutions of higher learning in South Africa: The strategies, complexities and realities. Journal of Social Science, 35(2), 97-109. http://dx.doi.org/10.1080/09718923.2013.11893151

Serkan Ozmen, (2018). How employees define organizational trust: analyzing employee trust in organisation. Journal of Global Responsibility, 9(1), 21-40, http://dx.doi.org/10.1108/JGR-04-2017-0025

Shahzadi, I, Javed, A, Pirzada, S, Nasreen, S, \& Khanam, F. (2014), Impact of employee motivation on employee performance. European Journal of Business and Management, 6(23), 159-166. Retrieved from www.iiste.org

Shenkel, R. \& Gardner, C. (2004, December). Five ways to retain good staff. Family Practice Management, 57-59. Retrieved from https://www.aafp.org/fpm/2004/1100/p57.pdf

Shockley-Zalabak, P., Ellis, K. \& Winograd, G. (2000). Organizational trust: what it is, why it matters. Organization Development Journal, 18(4), 35-48. Retrieved from https://search-proquest-com.library.sheridanc.on.ca/docview/197985640?accountid=3455

Shuck, B., \& Herd, A. M. (2012). Employee engagement and leadership: Exploring the convergence of two frameworks and implications for leadership development in HRD. Human Resource Development Review, 11(2), 156-181. http://dx.doi.org/10.1177\%2F1534484312438211

Steers, R. M. \& Mowday, R. T. (1981). Employee turnover and post-decision accommodation processes. In L. L. Cummings and B. M. Staw (Eds.), Research in Organizational Behavior. JAI Press: Greenwich, CT.

Stokes, J., Riger, F., \& Sullivan, S. (1995). Relationship between job satisfaction and retention rate. Retrieved from: http://dx.doi.org/10.1111/j.1471-6402.1995.tb00091.x/abstract.

Tyler, T. (2003). Trust within organizations. Personnel Review, 32(5), 556-568. http://dx.doi.org/10.1108/00483480310488333

Udechukwu, I. I., \& Mujtaba, B. G. (2007). Determining the probability that an employee will stay or leave the organization: A mathematical and theoretical model for organizations. 
Human Resource Development Review, 6(2), 164-184. http://dx.doi.org/10.1177/1534484307300239

Van der Berg, Y. \& Martins, N. (2013). The relationship between organizational trust and quality of work life. SA Journal of Human Resource Management, 11 (1), 1-13. http://dx.doi.org/ 10.4102/ sajhrm.v11i1.392

Uzonna, U. R. (2013). Impact of motivation on employees performance: A case study of Credit West Bank Cyprus. Journal of Economics and International Finance, 5(5), 199-211. http://dx.doi.org/10.5897/JEIF12.086

Wan-Huggins, V. N., Riordan, C. M., \& Griffeth, R. W. (1998). The development and longitudinal test of a model of organizational identification. Journal of Applied Social Psychology, 28(8), 724-749. http://dx.doi.org/ 10.1111/j.1559- 1816.1998.tb01728.

Wells, J. E., \& Peachey, J. W. (2011). Turnover intentions: Do leadership behaviors and satisfaction with the leader matter? Team Performance Management: An International Journal, 17(1/2), 23-40. http://dx.doi.org/10.1108/13527591111114693

\section{Copyright Disclaimer}

Copyright for this article is retained by the author(s), with first publication rights granted to the journal.

This is an open-access article distributed under the terms and conditions of the Creative Commons Attribution license (http://creativecommons.org/licenses/by/3.0/). 